\title{
The Key Triggers for the Transitioning of Informal SMMEs to Formal SMMEs: A Baseline Survey of the Gauteng Province-South Africa
}

\author{
Paul Kibuuka, Deon Tustin \\ University of South Africa (UNISA), Gauteng, South Africa
}

\begin{abstract}
This paper presents the views of 623 informal and formal small, medium, and micro enterprises (SMMEs) operating in the Gauteng Province of South Africa. The objective of the study was to identify challenges and benefits that are experienced by SMMEs during and after the registration process leading to the transition from informal to formal business, the level of awareness by the SMMEs of the registration information, and the procedures in addition to the potential factors that inspire or discourage informal and prospective business registration. The reason for including both informal and formal SMMEs in the survey was to compare the perceptions of these groups of businesses regarding the triggers and/or barriers to register as a formal business. The results show that for both informal and formal businesses, the liability of paying taxes was a major challenge while improved workers' health and safety accrued as a major benefit. Own research emerged as the main source of access to business registration information and procedure. The costs involved in registration were highlighted as one of the major factors discouraging registration but the prospects of expanding the customer base and the ability to achieve a higher turnover as some of the main inspiring factors. The study recommends the development of policies that provide an enabling environment for sustainable enterprises but also to implement measures that improve productivity through access to finance, skills, infrastructure, markets, and technology transfers.
\end{abstract}

Keywords: SMME, informal, triggers, business registration, transition, formal, employees, turnover and South Africa

\section{Introduction}

Informal firms make up a major share of the economy in most developing countries. Expanding formalisation could increase government tax revenues, boost firm profits, and national income and increase employee well-being by improving access to social security and health and workers' benefits. Reforms to encourage firms to register include simplifying procedures, reducing the cost and time to register, and making more information available on registration procedures. Reforms might not result in higher registration and formalisation. In some cases, better enforcement and wider development policies might be needed as well (IZA World of Labor, 2014). The importance of small and medium enterprises (SMEs) in South Africa is witnessed in terms of the contribution towards the gross domestic product (GDP) and employment creation across numerous sectors of the economy. Although SMEs contribute as little as $25 \%$ to capital formation compared to 
large enterprises, it is noticeable that they have a major socio-economic role to play in the country. Based on the report by the Task Group of the Policy Board for Financial Services and Regulation (2013), the estimated contribution of SMEs to GDP in South Africa stands at more than 50\%, while the contribution to employment stands at more than $60 \%$.

\section{Theoretical Model for Enterprise Life-Cycle}

Hank, Watson, Jansen, and Chandler (1993), mainly using exploratory cluster analysis of cross-sectional data supplied via mailed questionnaire by 133 manufacturing SMEs from "high technology" industries in the United States, derived a life-cycle model with four development stages and two disengagement (or arrested development) stages, as represented in Figure 1. Hank et al. (1993) further described the various development configurations or stages in their taxonomic life-cycle model as follows:

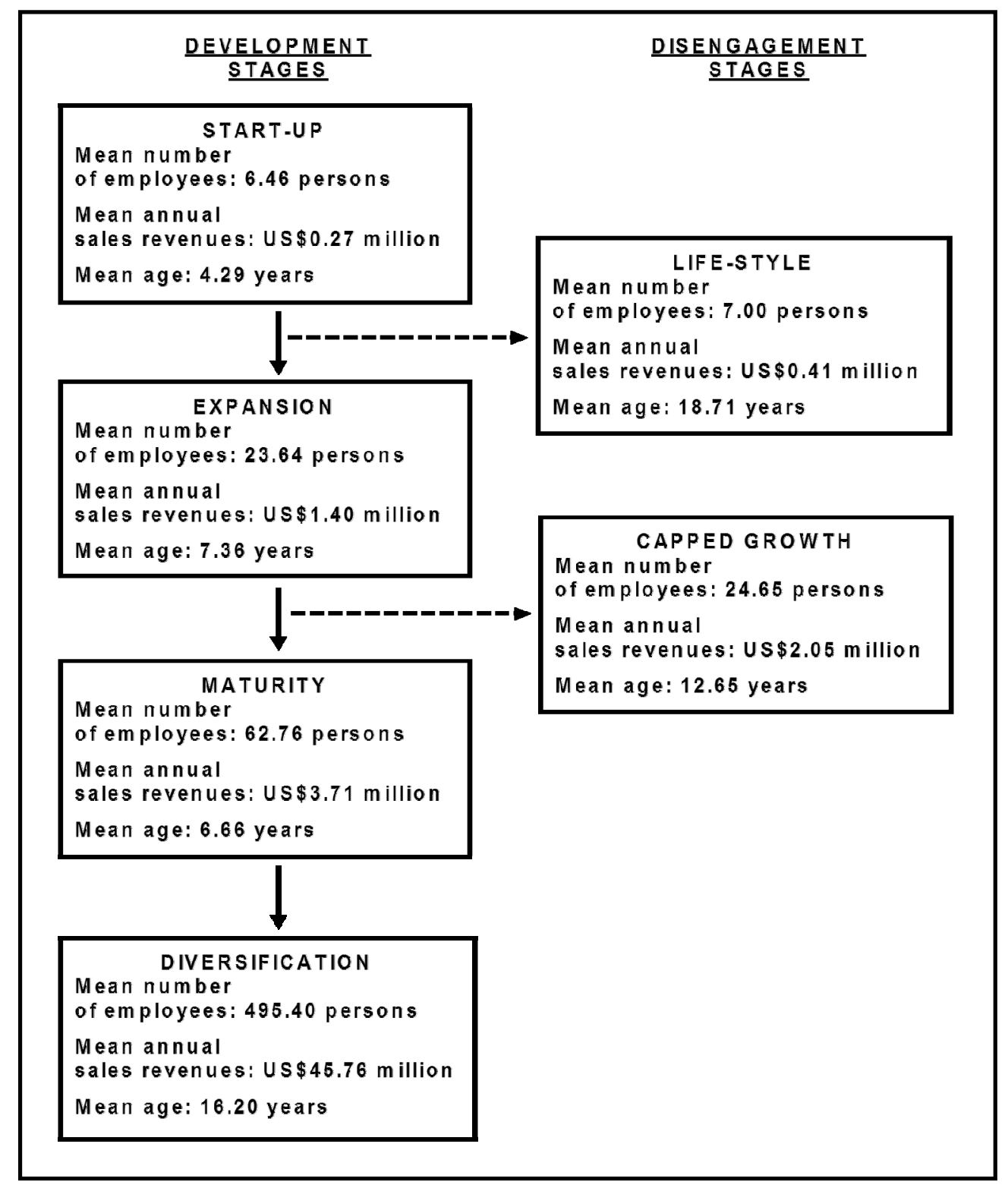

Figure 1. Enterprise life-cycle model (Hank et al., 1993). 
- Start-up-young, small enterprises with simple organisational structures and a mean of 2.20 organisational levels. There is little functional specialisation, with a mean of 1.50 specialised functions. Product development appears to be the focal priority.

- Expansion - slightly older and larger enterprises with more complex organisational structures and a mean of 3.18 organisational levels. The organisation is still very centralised and is a little more formal than in the start-up stage.

- Maturity —although not necessarily older, on average, than in the expansion stage, enterprises in this stage are typically more than twice as large. Centralisation is declining and formalisation increasing.

- Diversification - enterprises are generally medium-sized with increasing tendency to have divisionalised structures. There is a mean of 5.70 organisational levels. Centralisation is low, and formality is highest for any stage in the life-cycle model.

It is particularly notable that the generally increasing size and age of enterprises when reading down this list of life-cycle stages provides some evidence that businesses may, in some sense, progress sequentially through the stages as they evolve and develop. Kazanjian and Drazin (1989) make a similar point based on findings of their study of growth in technology-based concerns (McMahon, 2014).

\section{Literature Review}

\section{Defining SMMEs}

According Tassin (2014) defining small, medium, and micro enterprises (SMMEs) is not an easy task. The literature search reveals a plethora of definitions. These definitions do not only differ between countries but even within countries, there are noticeable differences. In South Africa, SMMEs are normally defined in accordance with the National Small Business Act of 1996 as amended in 2003 and 2004 which defines SMMEs as: "A separate and distinct business entity, including co-operative enterprises and nongovernmental organisations, managed by one owner or more which, including its branches or subsidiaries, if any, is predominantly carried on in any sector or sub-sector of the economy and which can be classified as micro, a very small, a small or a medium enterprise". The National Small Business Act of 1996 (as amended in 2003 and 2004) categorises SMMEs into distinct groups, namely; survivalist, micro, very small, small, and medium micro-enterprises.

To be more specific, the National Small Business Act of 1996 (as amended in 2003 and 2004) provides the following classifications for SMMEs in South Africa.

- Businesses with fewer than 200 employees, with an annual turnover of less than 40 million rands, and gross asset value of less than 18 million rands are regarded as medium enterprises.

- Businesses with less than 50 employees, with less than 25 million rands in total annual turnover, and less than 4 million rands gross asset value as small enterprises.

- Businesses belonging to the "very small" category are those with less than 10 employees, with less than 4 million rands annual turnover and less than 1.8 million rands gross asset value.

- Businesses with less than 5 employees, with less than 0.15 million rands annual turnover, and less than 0.10 million rands asset value are regarded as micro.

- Businesses with no paid employees, with less than the minimum income standard, asset value, or poverty line belong to the survivalist. 


\section{Drivers of Formalisation of SMMEs}

Like Wickham (2001, p. 77) and Dzansi (2004, p. 48) argue that SMMEs make more impact on society when they adopt strategic objectives of growth; market development; increased market share; and market positioning. But adopting any of these strategic postures will require formalising the business. Firm growth, for instance, will require any informal micro enterprise to raise capital and no investor or lender could be willing to inject money into an unregistered business because there is no traceability. Thus from a strategic management or strategic entrepreneurship perspective, it makes sense for an informal business to formalize its operations

It can be argued that long term or strategic motives drive informal business owner/manager's decision to formalize or not to. These motives are the reasons for formalization which amongst others may include the vision and ambition of business owners to grow their business. Should the owner/manager decide to formalize, there are challenges to contend with (USAID, 2005, p. 17). Challenges of formalisation consist of inter alia complex regulatory processes, bureaucracy, and tax issues (USAID, 2005, p. 17). Further, it is argued that the ability of an informal business to successfully negotiate these challenges will depend on certain background and personal traits of owner managers. That is, in the end, only businesses whose owners/managers possess the right attributes to overcome the challenges will be able to transit (graduate) to a formal business.

\section{Contribution of SMMEs to Socio-economic Well-Fare}

A study on the global economy conducted by the Edinburg Group (2012, p. 7) revealed that although SMMEs constitute more than $95 \%$ of enterprises across the world, they account for approximately $60 \%$ of private sector employment. A report on SMMEs in Japan compiled by the Economist Intelligence Unit (2010, p. 3) reveals that among the industrialised countries, Japan has the highest proportion of SMMEs and these employ more than $99 \%$ of the total working population of Japan.

In high-income countries, the backbone of the economy is the SMME sector. Though making a lesser percentage of employment, the SMME sector also makes a critical contribution to employment and GDP in low-income countries. SMMEs in high-income countries contribute $66 \%$ of employment as opposed to $78 \%$ of employment in low income countries and 13\% to GDP as opposed to $47 \%$ respectively. Practitioners and researchers seem to agree that SMMEs are crucial contributors to economic growth and job creation in most countries (Edinburg Group, 2012; Dalberg, 2011; OECD, 2006).

In most developing and emerging economies, the SMME sector has played significant roles in achieving development targets. In Malaysia, the sector contributed about 33\% to national GDP of 2011 and is expected to make a $40 \%$ contribution by 2020 through what the Malaysian government calls the SMME "master plan" (StatsOnline, 2013).

In India, though SMMEs contribute only $17 \%$ to national GDP, they employ more than $40 \%$ of the workforce thus providing some form of sustenance to lower middle class and working class population groups (Adarsh, 2011). Padmadinata (2007) notes that in Indonesia SMMEs made a total contribution of $99.9 \%$ of total enterprises in the country. This amounted to close to 50 million SMMEs, which were created in the previous year, providing, work for more than 85 million people (Pandya, 2012).

Abor and Quartey $(2010$, p. 219) estimate that $91 \%$ of formal entities are SMMEs in South Africa. Tshabalala (2007, p. 1) argues that SMMEs make an important part of any economy. With more than $91 \%$ of 
all businesses in South Africa being described as SMMEs, contributing about $40 \%$ of all economic activity in the country, their importance remains critical to the socio-economic growth of the nation. StatsOnline (2013) mentions that the unemployment rate in South Africa currently stands at $25.2 \%$ and SMMEs have the ability to reduce unemployment and eliminate poverty through job creation. The provision of these jobs has a multiplier effect such as employment and innovation on the workers who depend on these salaries.

As earlier discussed, SMMEs also contribute to the GDP of a country or region. In the South African context, it is estimated that SMEs contribute $42 \%$ of the country's GDP. This occurs through SMEs' contribution of up to $50 \%$ of all formal employment (Ayyagari, Beck, \& Demirgüç-Kunt, 2005). The results of a comparative study on issues of SME development in Ghana and South Africa however revealed that SMMEs in South Africa contribute about 52\% to 57\% of GDP (Abor \& Quartey, 2010, p. 219).

The above section has provided evidence from the literature of the contribution of SMMEs to economic growth. What remains of interest to this study is the level of support for the SMME sector. SMMEs need support if they are to make a positive contribution to the socio-economic development of any country. The section below presents a review of the literature on SMME enabling environment with a special focus on the South African SMME support environment.

\section{SMMEs Enabling Environment}

It is arguably, only in the post-apartheid era that the South African economy began to place importance on SMMEs support and development (Rogerson, 2005). This support has especially been more practical than spontaneous in nature, with the aim of assisting different stages and sections in the development of SMMEs (DTI, 1995). Acknowledging the importance of SMMEs, many countries and governments strive to create a favourable environment for the birth and growth of SMMEs hence making the development of policies to advance a viable SMME environment their top priority (Dzansi, 2006, p. 43). In South Africa, the National Small Business Act 102 of 1996 and the Government White Paper on National Strategy for the Development and Promotion of Small Business of 1995 are the two main instruments used by the South African government to stimulate the growth of small businesses in the country.

\section{Research Objective}

In the context of this study, the term formalisation relates to the process of transforming informal firms and jobs to formal ones by registering with the government. The objective of the study was to identify challenges and benefits that are experienced by SMMEs during and after the registration process leading to the transition from informal to formal business, the level of awareness by the SMMEs of the registration information, and the procedures in addition to the potential factors that inspire or discourage informal and prospective business registration. The reason for including both informal and formal SMMEs in the survey was to compare the perceptions of these groups of businesses regarding the triggers and/or barriers to register as a formal business.

\section{Research Methodology}

The research methodology of the baseline study of the transitioning of informal SMMEs comprised both quantitative and qualitative research approaches as indicated in Table 1. The quantitative research approach targeted 623 respondents of informal and formal businesses through computer aided telephone interviews (CATI) (77.8\%) and face-to-face interviews (22.2\%). The sampling frame of the formal businesses consisted of 
the local telephone directories of the six districts in the Gauteng Province namely: the City of Johannesburg Metropolitan Municipality, City of Tshwane Metropolitan Municipality, Ekurhuleni Metropolitan Municipality, Metsweding District Municipality, Sedibeng District Municipality, and Westrand District Municipality. In turn, informal businesses involved operational informal enterprises in the four major townships of Soweto (Johannesburg), Mamelodi, Tembisa, and Soshanguve (Tshwane). The sample selection of the formal businesses was performed utilising the systematic sampling technique to secure a total of 480 respondents while informal businesses were selected on a convenient/judgmental sampling basis to make a total of 143 . To comply to researcher ethics standards, the aim of the study was explained to respondents who were requested to consent to willingly participate in the study. Respondents were also guaranteed confidential treatment of inputs and were informed that all information supplied will be sourced for research purposes only.

Respondents in metropoles were covered via computer aided telephone interviews ( $n=485)$ while those in townships were enumerated through face to face interviews $(n=138)$. Qualitative research was conducted after the quantitative research, and entailed one focus group discussion comprising 10 participants of which six were owners of informal and four of formal businesses.

The study aimed to collect primary data from business owners, managers, or business partners of the SMMEs through personal face to face interviews. In this regard, the majority of respondents were either business owners $(65.7 \%)$ or managers $(15.1 \%)$. Figure 2 presents the main activities of the businesses sampled by economic sector. At $26.4 \%$ the highest proportion of businesses interviewed fell into the wholesale and retail, repair of motor vehicles, catering and accommodation sector followed by community, social and personal services $(21.8 \%)$, the least in agriculture, forestry, and fishing $(2.6 \%)$ and none in mining and quarrying $(0 \%)$.

Table 1

Formal and Informal SMME Research Methodology and Sample Distribution

\begin{tabular}{lll}
\hline Category & $n$ & $\%$ \\
\hline Quantitative Research Participants & & \\
CATI Interviews & 182 & 29.2 \\
City of Johannesburg & 115 & 18.4 \\
City of Tshwane & 123 & 19.7 \\
Ekurhuleni & 37 & 5.9 \\
Sedibeng & 28 & 4.6 \\
West Rand & 485 & 77.8 \\
Sub-total CATI & & 8.8 \\
\hline Face to Face Interviews & & 7.4 \\
\hline Soweto & 55 & 3.5 \\
Tembisa (East Rand) & 46 & 2.5 \\
Mamelodi & 22 & 22.2 \\
Soshanguve & 15 & 100.0 \\
Sub-total Face to face & 138 & $\mathrm{n} / \mathrm{a}$ \\
Total Quantitative Sample & 623 & \\
Qualitative Research Participants & & \\
1 focus group discussion of 10 participants (4 formal and 6 informal businesses) & 10 & \\
\hline
\end{tabular}




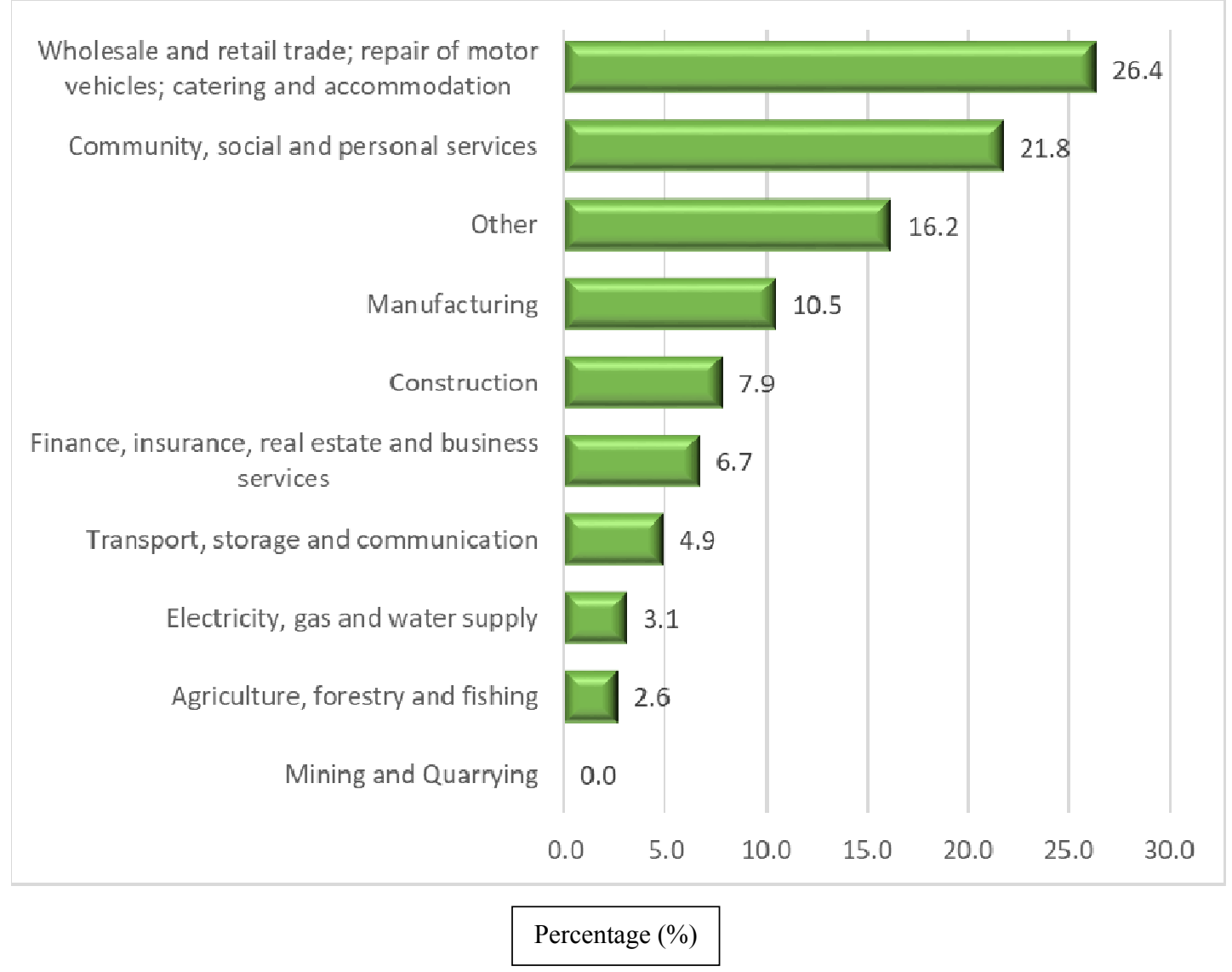

Figure 2. Main activity of the businesses interviewed by economic sector.

\section{Study Research Results}

\section{Drivers Promoting SMME Registration}

The research findings show that several difficulties/challenges (-) and benefits/opportunities $(+)$ are associated with registering an SMME business. Based on the views of the $600+$ participating formal and informal SMME owners/managers and business partners, these distinctions are captured and reported on per variable as a percentage of the total number of respondents and presented in Table 2.

A key determinant of investigating the ability of SMMEs transitioning was to explore the awareness of informal and formal businesses regarding access to business registration information/procedures. The results provided feedback in terms of the extent to which owners or managers of the businesses indicated that they were informed about the registration procedure. These findings are encapsulated in Table 3 where own research represents the main source providing access to business registration information for both informal and formal SMMEs.

The transitioning study also explored the potential factors that inspire and discourage informal/prospective business registration. These views of participating SMMEs are revealed in Table 4. It is notable that for the informal SMMEs the number of procedures/amount of paper work required ranks the highest discouraging factor while for formal SMMEs the lack of frequent and tangible registration reforms supersedes. The prospects of expanding the customer database is the most inspiring factor towards registration for both informal and formal SMMEs. 
Table 2

\section{Perceived Difficulties and Benefits of Business Registration}

\begin{tabular}{|c|c|c|}
\hline & Difficulties/challenges [-] & Benefits/opportunities [+] \\
\hline$\frac{\sum_{\infty}^{\infty}}{\sum_{0}^{\infty}}$ & $\begin{array}{l}\text { Registration procedures/paper work ("red tape") }(32.5 \%) \\
\text { Time and costs spent on accounting activities }(28.0 \%) \\
\text { Amount payable towards taxes }(25.0 \%)\end{array}$ & $\begin{array}{l}\text { General } \\
\text { Compliant with business regulations }(79.0 \%) \\
\text { Avoid risk of legal prosecution }(6.8 \%) \\
\text { Grow business }(5.5 \%) \\
\text { Specific } \\
\text { Improved worker health and safety } \\
\text { Improved access to social security and workers' health } \\
\text { Business can operate from a fixed location or property can be } \\
\text { registered under the business } \\
\text { Business operations improved in terms of marketing } \\
\text { Business operations improved in terms of expanding the } \\
\text { consumer base }\end{array}$ \\
\hline 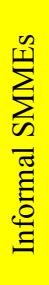 & $\begin{array}{l}\text { Business is not "large" enough to qualify for the } \\
\text { registration threshold }(27.2 \%) \\
\text { Lack of registration information }(26.3 \%) \\
\text { Lower profits will be generated }(13.6 \%) \\
\text { Business is only a temporary source of income until } \\
\text { employed }(11.2 \%) \\
\text { Liability of paying taxes }(10.4 \%) \\
\text { Affordability of licensing/renewal fees }(7.2 \%)\end{array}$ & $\begin{array}{l}\text { Specific } \\
\text { Improved marketing } \\
\text { Expanded customer database } \\
\text { Business can operate from fixed location } \\
\text { Improved workers' health and safety } \\
\text { Increased trade with suppliers } \\
\text { Improved access to finance }\end{array}$ \\
\hline
\end{tabular}

Table 3

Awareness of Business Registration in Formation/Procedures

\begin{tabular}{ll}
\hline Informal SMMEs & Formal SMMES \\
\hline $\begin{array}{l}46.9 \% \text { informed regarding registration procedure } \\
\begin{array}{l}\text { Main sources providing access to business registration } \\
\text { information/procedure: }\end{array}\end{array}$ & $\begin{array}{l}85.4 \% \text { familiar with registration procedure } \\
\text { Main sources providing access to business registration } \\
\text { information/procedure: }\end{array}$ \\
$\begin{array}{l}\text { Own research }(53.7 \%) \\
\text { Relatives/friends with business }(16.4 \%)\end{array}$ & $\begin{array}{l}\text { Own research }(53.2 \%) \\
\text { Government information centres }(11.9 \%)\end{array}$ \\
Business associations $(7.5 \%)$ & $\begin{array}{l}\text { Business absociations }(9.5 \%) \\
\text { Government information centres }(8.0 \%)\end{array}$ \\
\hline
\end{tabular}

Table 4

\section{Potential Factors That Inspire [+] or Discourage [-] Informal/Prospective Business Registration}

\begin{tabular}{|c|c|c|}
\hline & Informal SMMEs & Formal SMMES \\
\hline 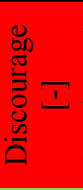 & $\begin{array}{l}\text { Number of procedures/amount of paper work required } \\
\text { Costs involved in registration too expensive } \\
\text { Not able to afford the annual registration fees or the } \\
\text { renewal of licenses }\end{array}$ & $\begin{array}{l}\text { Lack of frequent and tangible registration reforms } \\
\text { Accounting fees and compliance paper work } \\
\text { Stringent labour regulations } \\
\text { Minimum capital requirements/cost of registration } \\
\text { Quality and reliability of municipal service delivery }\end{array}$ \\
\hline 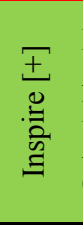 & $\begin{array}{l}\text { Prospects of expanding customer database } \\
\text { Ability to achieve higher turnover } \\
\text { More information on registration process } \\
\text { Ability to freely market business } \\
\text { Government subsidised registration fees }\end{array}$ & $\begin{array}{l}\text { Prospects of expanding customer database } \\
\text { Ability to freely market business } \\
\text { More information on registration process } \\
\text { Simplifying the registration process by reducing time and cost } \\
\text { of registration } \\
\text { Ability to achieve higher turnover }\end{array}$ \\
\hline
\end{tabular}

Business operation impediments form an important dynamic when considering business transitioning. Consequently, Table 5 highlights the major factors that impact on the business operations of participating 
formal and informal SMMEs. Though the rankings may differ, there is a significant convergence in the factors identified ranging from paying taxes, getting electricity, protecting investors, corruption to getting credit.

Table 5

Main Factors Affecting Ease of Operating an SMME Business

\begin{tabular}{ll}
\hline Informal SMMEs & Formal SMMEs \\
\hline Starting a business & Paying taxes \\
Getting electricity & Enforcing contracts \\
Protecting investors & Resolving insolvency \\
Paying taxes & Electricity supply \\
Enforcing contracts & Protecting investors \\
Corruption & Corruption \\
Getting credit & Getting credit \\
\hline
\end{tabular}

\section{Total Number of Permanent Employees and Annual Revenue of the Businesses During the Financial Year Preceding First Registration}

In this analysis, the study intended to shed some light on the critical thresholds in terms of levels of employment and annual revenue at which the formal business owners, managers, and business partners in the sample succumbed to the need to register their businesses in order to qualify for the benefits. The results reflected in Table 6 show that the highest number of respondents (30.3\%) employed 1-3 employees in year proceeding the registration of their business followed by entities with a payroll of 4-7 employees (24.5\%). Regarding the level of business annual revenue tipping point, $63.5 \%$ reported a level of R0-R499,999 followed by $24.3 \%$ for R500,000-R999,9999 in the year preceding first registration.

Table 6

Number of Permanent Employees Before Registration

\begin{tabular}{lll}
\hline & $n$ & $\%$ \\
\hline None (i.e., owner(s) only) & 47 & 11.4 \\
$1-3$ employees & 125 & 30.3 \\
$4-7$ & 100 & 24.3 \\
$8-15$ & 64 & 15.5 \\
$16-24$ & 16 & 3.9 \\
$25-49$ & 20 & 4.8 \\
$50-99$ & 5 & 1.2 \\
$100+$ & 14 & 3.4 \\
Don't know/confidential & 21 & 5.1 \\
Total & 412 & 100.0 \\
\hline
\end{tabular}

\section{Business Expectations After Registering}

During the focus group discussions, business tax obligations emerged to be the main issue that a number of business highlighted regarding business expectations after registering. A general feeling among the businesses was that higher taxation would erode their profits. This sentiment was shared by registered business owners who alluded that after registering their businesses, they were subjected to higher tax burdens and also had a challenge of acquiring adequate administrative skills to deal with the tax requirements. As a result, some of the businesses were unable to meet their tax obligations timely leading to higher tax penalties that adversely affected the sustainability of their businesses. 


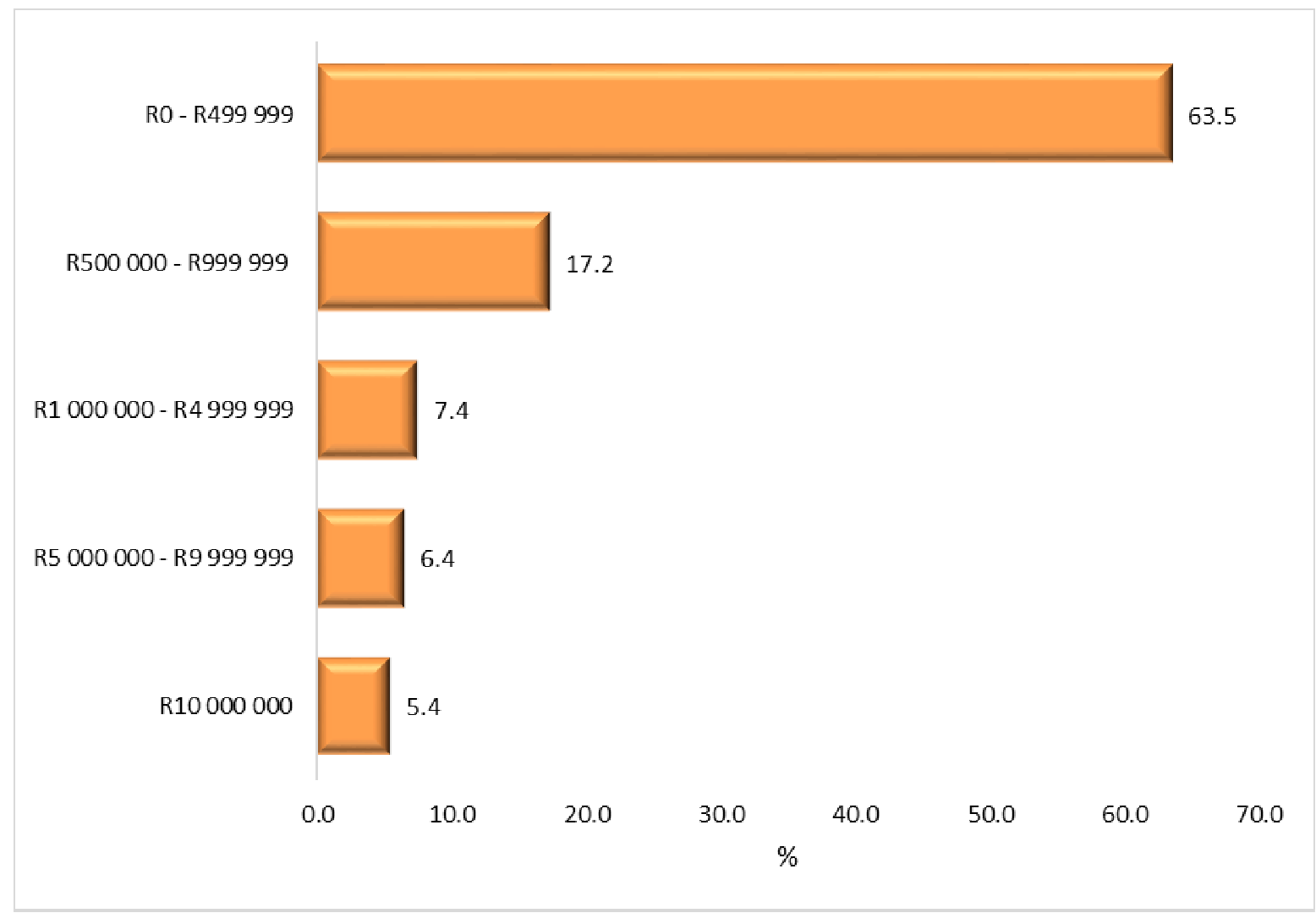

Figure 3. Annual revenue before registration.

Although clear advantages for transitioning from informal to formal business are evident from the study, there remains certain challenges at macro (i.e., economic, political, and technological developments), meso (i.e., market forces such as supply and demand, strategic partnerships), and micro (i.e., resources, products, and services) levels that should be considered when formulating integrated policies to guide future business transitioning. Importantly the research builds on international research by the International Labour Organization (ILO, 2014) on facilitating transitions from the informal to the formal economy. Whereas the ILO approach to the transition to formality focuses on fundamental principles and rights at work, employment, social protection and dialogue, the study presents a true business perspective on the research topic. Consequently, the business transitioning study contributes to the development of a knowledge economy to guide future business policies and development.

The analysis conducted up to now is critical to judge the prospects of informal to formal business transitioning. This information is consolidated in the summary and recommendations. The discussion serves to highlight the key factors that will largely direct business transitioning from informal to formal business.

\section{Conclusions and Implications for South Africa}

The results confirm that the five critically important discouraging factors to address are those experienced by formal business owners during their journey to formality. These in order of importance include: (i) the lack of frequent and tangible registration reforms, (ii) accounting fees and compliance paper work, (iii) stringent labour regulations, (v) minimum capital requirements/cost of registration, and (v) quality and reliability of municipal service delivery. 
It is also important to consider and address the current critical factors that discourage informal business owners or managers from registering their businesses. The leading factor pointed out was the cost of annual licensing renewals and registration fees followed by accounting fees and compliance paper work, stringent labour relations, paying taxes, and quality and reliability of basic needs service delivery.

Although there are a number of similarities highlighted in terms of the main factors affecting the ease of operating an SMME business, there is also a significant divergence in terms of the ranking of the factors. The only convergence is observed for the lowest ratings accorded to corruption and getting credit. This matter needs concerted attention by both government and private sector in order to promote both entrepreneurship and enterprise development. In this regard it is important to focus on promoting regulatory reform that strengthens the ability of the private sector to create jobs, lift people out of poverty, and create more opportunities for the economy to prosper. The notion that the private sector has substantial economic, social, and developmental impact is now universally recognised. Policy reforms catalyse private investment. Promoting a well functioning private sector is a major undertaking for any government. It requires long-term policies of removing administrative barriers and strengthening laws that promote entrepreneurship.

During the focus group discussions, a number of small business owners felt that ease of accessibility and simplification of the registration information, processes, and requirements would encourage businesses to register. A change of mind-set among small businesses was also seen to be a crucial element that would enable businesses to realise the benefits of registering a business. It was further emphasised that registering businesses would yield more empowerment of businesses in terms of skills development and training to instill more confidence among business owners, as a result a number of businesses would be encouraged to register. Small businesses also pointed out that without adequate support they would not benefit from the opportunities available after registering. The issue of corruption remained problematic as the general feeling among the business owners was that there is high level of corrupt activities in a form of bribery among officials' responsible providing assistance and support to small businesses.

\section{Recommendations}

From an administration perspective attention to and simplification of the business registration procedures/paper work ("red tape"), time and costs spent on registration and accounting activities, registration, and license renewal cost and tax obligations of especially small SMMEs require careful consideration. Part of this challenge can be addressed by providing adequate information to better guide the registration of informal or prospective businesses or to market the availability of registration information sources and requirements more extensively among smaller businesses. Metropolitan and District Municipalities could play a major role in this regard during business stakeholder collaboration sessions. Own efforts to gain business registration information (i.e., independent research, references, and networks and social media) should further be encouraged.

Ease of stringent labour laws and improved municipal service delivery (i.e., access to electricity supply) also require special attention to entice informal or prospective SMMEs to register their business.

Alleged corruption in government departments issuing company registration certificates and providing business advise should be investigated.

Business registration can potentially improve workers' health and safety and social security and secure better marketing (by being included in formal business databases), a broader customer base, skills development, 
improved business growth, and higher turnover. For smaller-sized SMMEs registration may also secure easier access to finance as well as increased contracts with government and private business. These advantages may not be as lucrative for informal business that operate in township economies where cannibalisation by formal big businesses seems to remain a reality. From a macro-economic perspective, SMME business growth in general will only be feasible in a "corruption free" and growing economy. Alongside this, South African requires the development of a business registration and investment culture and changed business mind-set that will timely realize the potential benefits of registering a business. Established large business will have a major role in this challenge by collaborating with SMMEs for the purpose of capacity building, experience and entrepreneurial skills development. Both big business and government should demonstrate their commitment towards SMMES by not being partial towards the issuing of contracts to large and established business only. Also, the role and involvement of universities in SMME skills development should not be overlooked. In this regard, the expansion or establishment of entrepreneurial hubs at higher education institutions could play a significant role. Universities of higher education can also play an important role in the research required to determine, among other, the market potentials for unregistered and prospective registered business. Such efforts may also contribute to balance demand and supply side forces in support of business development taking into consideration the informal sector's diversity, performance, and business saturation within different sectors of the South African economy.

Internationally and locally, the transition from the informal to the formal economy will remain an important issue in the years to come. By advocating that the study should be replicated in other provinces of South Africa, such complementary research will continue to contribute to the desired production of a knowledge economy in support of an integrated policy framework for business transitioning. The Gauteng study confidently provided a valuable assessment and diagnosis of factors, characteristics, causes, and circumstances of informality within a provincial context which could be applied by decision-makers to inform the design and implementation of laws and regulations, policies and other measures aiming to facilitate the transition from the informal to the formal economy in South Africa. Ideally, such policies must create an enabling environment for sustainable enterprises and facilitate the implementation of measures to improve productivity through access to finance, skills, infrastructure, markets, and technology transfers.

\section{References}

Abor, J., \& Quartey, P. (2010). Issues in SME development in Ghana and South Africa. International Research Journal of Finance and Economics, 39(6), 215-228.

Adarsh, G. D. P. (2011). Information system development approach: Facts from IT SMEs in India. International Journal of Business Information Systems, 8(4), 361-379.

Ayyagari, M., Beck, T., \& Demirgüç-Kunt, A. (2005). Small and medium enterprises across the Globe: A new database. World Bank Policy Research Working Paper 3127.

Dalberg, P. (2011). Report on support to SMEs in developing countries through financial intermediaries. Retrieved from https://www.eib.org/attachments/dalberg_sme-briefing-paper.pdf

DTI (Department of Trade and Industry). (1995). White paper on national strategy for development and promotion of small businesses in South Africa. Government Gazette. Pretoria: Government Printers.

Dzansi, D. Y. (2004). Social responsibility of SMMEs in rural communities (Ph.D. Thesis, University of Pretoria, South Africa).

Dzansi, D. Y. (2006). An analysis of the adjustment problems of international students in a South African university (MA, University of the Free State).

Economist Intelligence Unit. (2010). Digital economy rankings. Beyond e-readiness. A report from the Economist Intelligence Unit. 
Edinburg Group. (2012). Growing the global economy through SMEs. Retrieved from http://www.edinburgh-group.org:http://www.edinburgh-group.org/media/2776/edinburgh_groupresearch_-_growing_the_glo bal_economy_through_smes.pdf

Hank, S. H., Watson, C. J., Jansen, E., \& Chandler, G. N. (1993). Tightening the life-cycle construct: A taxonomic study of growth stage configurations in high-technology organizations. Entrepreneurship Theory and Practice, 18(2), 5-29.

ILO (International Labour Organization). (2014). Transitioning from the informal to the formal economy. International Labour Conference, 103rd Session. Geneva.

IZA World of Labour. (2014). Annual Bank Conference on Development Economics. The Role of Theory in Development Economics. Washington DC, USA.

Kazanjian, R. K., \& Dragin, R. (2013). An empirical test of a stage of growth progression model. Emory Business School, Emory University, Atlanta, Georgia.

McMahon, R. G. P. (2014). Stage models of SME growth reconsidered. The Flinders University of South Australia. Adelaide, South Australia.

OECD (United States Agency International Development). (2006). Removing barriers to formalization. In Promoting pro-poor growth (pp. 75-84). Private Sector Development.

Pamadinata, U. (2007). The importance of SME Innovation Center in Indonesia SME condition in Indonesia. Retrieved from http://www.apecsmeic.org/newsletter/newsletter_read.jsp?SEQ= 387

Pandya, V. M. (2012). Comparative analysis of development of SMEs in developed and developing countries. The 2012 International Conference on Business and Management, Phuket-Thailand. Gujarat National Law University. Gandhinagar-India.

Republic of South Africa. (1995). White paper on national strategy for the development and promotion of small business in South Africa. Pretoria: Government Printers.

Republic of South Africa. (1996). National Small Business Act 102 of 1996. Pretoria: Government Printer.

Republic of South Africa. (2004). National Small Business Amendment Act, 2004. Accessed 25/03/2013. Retrieved from http://www.info.gov.za/view/DownloadFileAction?id=67967

Rogerson, C. M. (2005). Developing small firms in township tourism: Emerging tour operators in Gauteng, South Africa. Urban Forum, 16(2-3), 196-213.

StatsOnline. (2013). Statistic South Africa [Online]. Accessed 29/03/2013. Retrieved from http://www.statssa.gov.za/keyindicators/keyindicators.asp

Task Group of the Policy Board for Financial Services and Regulation. (2013). SME's success access to finance in South Africa-A supply side regulatory review. Pretoria.

Tassin, R. E. N. (2014). Transitioning from informal to formal business: Motives, challenges and coping mechanisms of selected transited business in the Bloemfontein area. Retrieved from http://hdl.handle.net/11462/235

Tshabalala, D. B. (2007). The strategic issues management by small businesses in the Mamelodi Metropolitan areas. Pretoria.

USAID (United States Agency International Development). (2005). Barriers to formalization. The case for reform and emerging best practice. Accessed 20/06/2012. Retrieved from http:/www.oecd.org/development/povertyreduction/38452590.pdf

Wickham, P. A. (2001). Strategic entrepreneurship: A decision making approach to new venture creation and management (2nd ed.). London: Pearson Education. 